\title{
HIERARCHICAL DECISION-MAKING PROBLEMS - MODELING AND SOLUTIONS
}

\author{
Tadeusz KRUPA*, Teresa OSTROWSKA** \\ Warsaw University of Technology, Faculty of Management, Warsaw, Poland \\ *e-mail: Tadeusz.Krupa@pw.edu.pl \\ **e-mail: Teresa.Ostrowska@pw.edu.pl
}

\begin{abstract}
Article illustrates the state of the work conducted at the Faculty of Management Warsaw University of Technology on the issue of modeling hierarchical decision-making problems in the context of administrative and infrastructural conditions of the various forms of public safety. The aim is to develop a universal methodology of conduct for the management needs of the public administration, whose powers are focused on maintaining the continuity of the critical infrastructure of the State. The key issues covered by the article are: modeling of hierarchical issues and decision-making processes in the multi-layered organizational structures; harmonization of scales significance of decisionmaking areas with significance weights of elementary decisions in these decision areas; and a priori contradictions of elementary decisions from different decision areas and value assessments of taken problem decisions.
\end{abstract}

Keywords: flat and hierarchical decision problem, standardization and harmonization of weights significance areas of decision-making, problem decisions and elementary decisions, cumulative value of problem decision, inner and inter-territorial a priori contradictory elementary decisions formalization of decision making process in hierarchical structure.

\section{$1 \quad$ Introduction}

The essence of the decision-making process in large organizations is to solve strategic (S), tactical (T) and operational $(\mathrm{O})$ decision problems and to take adequate decisions in their multi-layered decisionmaking hierarchical structure (HSD). Inside the hierarchical structure they are solved with mainly flat decision-making problems (FPD) and executed the resulting operational decisions.

At the tactical $\mathrm{T}$ and strategical $\mathrm{S}$ layers, in search of elementary decisions, are formulated and solved hierarchical decision-making problems (HPD) and resulting decisions.

Strategic $\mathrm{S}$, tactical $\mathrm{T}$ and operational $\mathrm{O}$ decision problems, and the resulting from them tasks belong to given organizational structures and competencies of their staff. In other words, on the HSD model of the existing organization, HPD network models of competence are applied, which often cause that there are many contradictions between: decisions, accompanying regulations and resources needed to implement them.

In such a situation, it becomes necessary to use a specially developed methodology proceedings, which provides a balanced and coordinated decisionmaking problem solving, resulting in $\mathrm{S}, \mathrm{T}$ and $\mathrm{O}$ layers, and also resulting from these decisions tasks to carry out in appropriate cells of organization. Decision-making in multilayer structures requires first and foremost modeling, simulation and reconciliation of decision variants both in terms of dynamic and iterative necessity of harmonization in order to optimize costs and minimize the risk associated to these processes.

Listed here actions are necessary in HSD large organizations in relation to the decisions taken at all levels from elementary decisions at the operational level, for example municipalities as state administrative unit and ending with the cumulative decisions taken at the higher tactical levels of government, for example in the districts or in the provinces.

The presented research results are the result derived from research conducted within the project of the National Research and Development Centre entitled "Highly specialized platform supporting civil emergency planning and rescue services in the public administration in Poland and in the organizational units $K S R G^{\prime \prime}$, implemented under the Competition No. 7/2015 on execution and financing of projects 
in the field of research and development work for the defense and security of the State - Agreement No. DOB - Bio7 / 11/02/2015.

Typical decision-making process is prepared in several stages (Krupa, 2006; Krupa, Ostrowska, 2007; Krupa, Ostrowska, 2012), among which should be distinguished development:

- model of the problem situation in which solutions of issues are being expressed,

- model specifying the decision about the all required features and characteristics of the measures taken,

- procedural model of problem solving solutions in the form: of a tree, which decomposition will lead to the transformation of the model of the problem situation into decision-making areas, decision saved as collections of forming sets (Krupa, Ostrowska, 2007; Krupa, Ostrowska, 2012) and elementary decisions in them.

Hierarchical decision problems (HPD) are being solved (see Fig. 3a, 3b, 5a) as a result of decomposition of the strategic decision-making problem $\mathrm{PD}^{\mathrm{S}}$ to the form of a pyramid tactical decision problems $\left(\mathrm{PD}^{\mathrm{T}}\right)$ and operational decision problems $\left(\mathrm{PD}^{\mathrm{O}}\right)$.

The theory of fuzzy sets (Zadeh, 1965; Krupa, 1998), as well as rough set theory (Pawlak, 1991) and the theory of characterization (Gorbatov, 1979; Gorbatov, Krupa, 1984; Krupa, 2009a; Krupa, 2009b; Krupa, 2013) allow the use of vague concepts in the formulation of decision problems and finding their solutions.
Theoretical concepts of blur or indistinguishable cases correspond to many real decision-making situations, appearing often in circumstances that threaten business continuity (Maj, Krupa, 2010; Ostrowska, 2013; Ostrowska, Krupa, Wiśniewski, 2015; Zawiła-Niedźwiecki, 2008; Zawiła-Niedźwiecki, 2010) or directly in crisis situations (Ficoń, 2007; Jajuga, 2007; Kieżun, 1997; Korzeniowski, 2012; Krupa, Wiśniewski, 2015; Kulińska, 2012; ZawiłaNiedźwiecki, 2009; Zawiła-Niedźwiecki, 2014).

Fast growing number of publications in this field proves the growing interest in the issue broadly defined national security and consequently methods of design, planning and decision-making in the State civil service.

A special case of hierarchical decision-making problems (HPD) are flat decision-making problems (FPD), which elementary decisions (see Fig. 1a, 3a), contained in the areas of decision-making, are not the subject of further decomposition.

Fig. 1a is an example of a strategic decision problem $\mathrm{PD}^{\mathrm{S}}$ containing only one strategic area of decisionmaking $\mathrm{OD}^{\mathrm{S}}$ with a repertoire of a three strategic elementary decisions $\mathrm{e}_{1}{ }^{\mathrm{S}}, \mathrm{e}_{2} \mathrm{~S}, \mathrm{e}_{3} \mathrm{~S}$. Among these decisions, $\mathrm{e}_{2} \mathrm{~S}$ was chosen (placed in the square) as the current strategic elementary decision. Each of the elementary strategic decision $\mathrm{e}_{i}^{\mathrm{S}}$ corresponds to the weight of significance $\mathrm{v}_{\mathrm{i}}^{\mathrm{S}}$, which is calculated in accordance with the formula (2b).

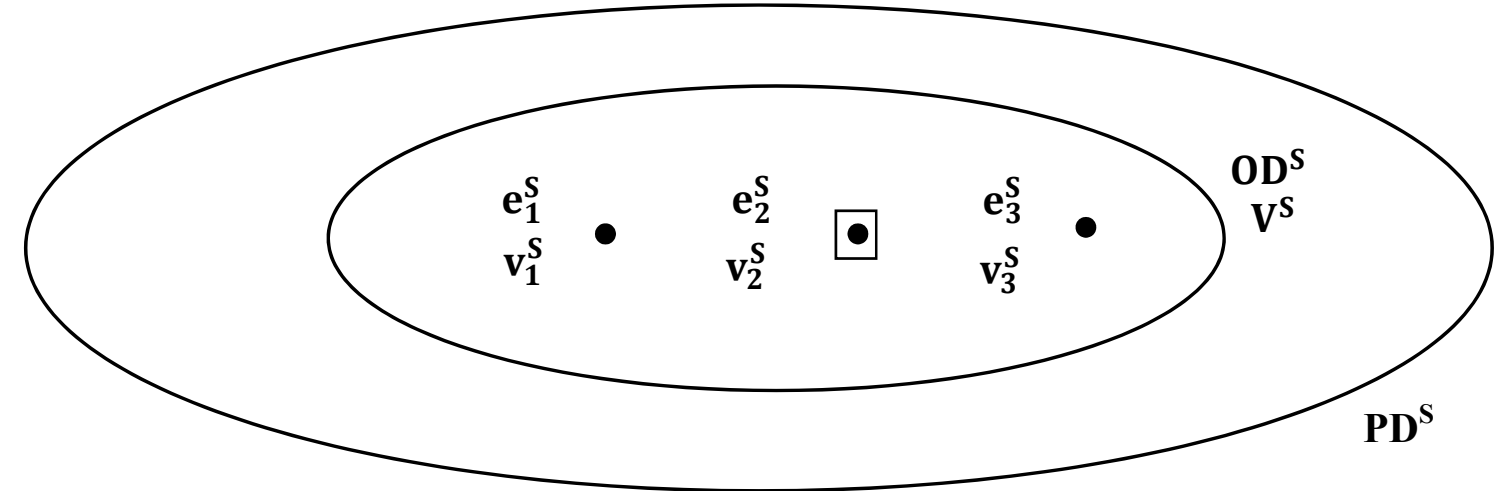

Figure. 1a. An example of strategic decision-making problem $\mathrm{PD}^{\mathrm{S}}$ with the indicated current elementary strategic decision $\mathrm{e}_{2}{ }^{\mathrm{S}}$ with a weight of significance $\mathrm{v}_{2}{ }^{\mathrm{S}}(\square$ - current decision) 
In the present case, the strategic decision-making area $\mathrm{OD}^{\mathrm{S}}$ corresponds to the weight of significance $\mathrm{V}^{\mathrm{S}}=1$, because it is the only one such area in the strategic decision problem $\mathrm{PD}^{\mathrm{S}}$ (for this reason, in the record $\mathrm{OD}^{\mathrm{S}}$ index $\mathrm{j}$ has been omitted.
Using the data shown in Fig. 1a a strategic decisionmaking problem PDS can be solved as it is shown at Table 1a., in which the value of each strategic elementary decision $\mathrm{e}_{\mathrm{i}}^{\mathrm{S}}$ is determined a priori, or is determined by the solution of tactical decision-making problem PD $^{\mathrm{T}}$ shown in Fig. 3a (see Table 3a).

Table 1a. The cumulative value of the elementary strategic decisions $e_{i}{ }^{S}$ and their weights significance $v_{i}{ }^{S}$ modified by the value of the weight of significance $\mathrm{V}^{\mathrm{S}}=1$ for strategic area of decision-making $\mathrm{OD}^{\mathrm{S}}$

\begin{tabular}{|c|c|c|}
\hline $\mathrm{e}_{1} \mathrm{~s}, \mathrm{v}_{1}{ }^{\mathrm{s}}, \mathrm{V}^{\mathrm{S}}$ & $\mathrm{e}_{2}{ }^{\mathrm{s}}, \mathrm{v}_{2}{ }^{\mathrm{s}}, \mathrm{V}^{\mathrm{s}}$ & $\mathrm{e}_{3}{ }^{\mathrm{s}}, \mathrm{v}_{3}{ }^{\mathrm{s}}, \mathrm{V}^{\mathrm{s}}$ \\
\hline
\end{tabular}

In every area of decision-making $\mathrm{OD}_{\mathrm{j}}$ on all layers of decision problems (strategic, tactical and operational), a square is used to fix elementary decisions indicating their participation in the areas of decisionmaking, contained in the layers of decision-making problems (see Fig. 3a, and 5a).

Shown in Fig. 1a an example of the $\mathrm{PD}^{\mathrm{S}}$ strategic decision-making problem contains only one $\mathrm{OD}^{\mathrm{S}}$ strategic area of decision-making with a repertoire of a three a priori limited strategic elementary decisions $\mathrm{e}_{1}{ }^{\mathrm{S}}, \mathrm{e}_{2}{ }^{\mathrm{S}}, \mathrm{e}_{3} \mathrm{~S}$, among which was chosen as the current elementary decision $\mathrm{e}_{2}{ }^{\mathrm{S}}$ placed in the square. Each of permissible $\mathrm{e}_{\mathrm{i}}^{\mathrm{S}}$ strategic elementary decision corresponds to the significant weight of $\mathrm{v}_{i}^{\mathrm{S}}$ determined in accordance with the formulas included in Table 3a.

\section{The issue of balance in the hierarchical decision problems}

The presented models of flat and hierarchical decision-making problems derive from the morphological analysis related areas of decision-making, were proposed in 1948 by F. Zwicky (1969).

The distinction between flat and hierarchical (multilayer) decision problems comes down to decide whether the decision problem formulated for a given problem can be solved without the need to examine the issues more specific and, therefore, to formulate for them separate decision-making problems. Thus, decisions on levels $\mathrm{S}$ and $\mathrm{T}$ should be taken as a solution of HPD, and operational decisions are, by definition, of FPD solution (see. Fig. 2a).
All data on the operational level should be achievable without the need for decision-making at lower altitudes of more detailed levels.

The need to compare significance weights of the decision-making problems PD in decision areas, and alternatives to their elementary decisions $e_{i, j}$ within the $\mathrm{OD}_{j}$ implies the need for so-called normalization of "small scales significance" $v_{i, j}$ for elementary decisions $\mathrm{e}_{\mathrm{i}, \mathrm{j}}$.

For modeling decision problems $\mathrm{PD}$, their decisionmaking areas $\mathrm{OD}_{\mathrm{j}}$ and elementary decision $\mathrm{e}_{\mathrm{i}, \mathrm{j}}$ belonging to these areas - have adopted the following findings:

- normalization of the weights of significance $\mathrm{v}_{\mathrm{i}, \mathrm{j}}$ elementary decision $e_{i, j}$ belongs to the area of decision-making $\mathrm{OD}_{\mathrm{j}}$ and is running according to the formula (2a) and should be done after every change $^{1}$ of the contracted value of at least one element $\mathrm{e}_{\mathrm{i}, \mathrm{j}}$

$\mathrm{v}_{\mathrm{i}, \mathrm{j}}=\mathrm{e}_{\mathrm{i}, \mathrm{j}} / \Sigma \mathrm{e}_{\mathrm{i}, \mathrm{j}}$

- bringing the weights of significance $\mathrm{v}_{\mathrm{i}, \mathrm{j}}$ elementary decisions within each area of decisionmaking $\mathrm{OD}_{\mathrm{j}}$ to normalize by the formula $(2 \mathrm{~b})$, where: $\mathrm{i}$ - is the index of elementary decisions $\mathrm{e}_{\mathrm{i}, \mathrm{j}}$ in the area of decision-making $\mathrm{OD}_{\mathrm{j}}, \mathrm{j}$ - is the index of $\mathrm{OD}_{\mathrm{j}}$ at the relevant decision problem PD, and $\mathrm{n}$ is the number of elementary decisions $\mathrm{e}_{\mathrm{i}, \mathrm{j}}$ in the considered $\mathrm{OD}_{\mathrm{j}}$ area

$\Sigma \mathrm{v}_{\mathrm{i}, \mathrm{j}}=\mathrm{v}_{1}+\mathrm{v}_{2}+\ldots+\mathrm{v}_{\mathrm{n}}=1$

\footnotetext{
${ }^{1}$ at the initial stage of the modeling assumes that the value $e_{i, j}=$ 1 for each $\mathrm{e}_{\mathrm{i}, \mathrm{j}} \in \mathrm{OD}_{\mathrm{j}}$
} 
For the entire decision-making problem $\mathrm{PD}$, separately for each complex decision operational $\mathrm{D}_{\mathrm{k}}{ }^{\mathrm{O}}$ $\mathrm{PD}^{\mathrm{O}}$, tactical a $\mathrm{D}_{\mathrm{k}}{ }^{\mathrm{T}} \quad \mathrm{PD}^{\mathrm{T}}$ and strategic $\mathrm{D}_{\mathrm{k}}{ }^{\mathrm{S}} \quad \mathrm{PD}^{\mathrm{S}}$ (if any of them is present in a given decision problem) complex decision $D_{k}$ of elementary decision $e_{i(k), j}$ is created using one elementary decision $e_{i(k), j}$ from each area of decision-making $\mathrm{OD}_{\mathrm{j}}$

$$
D_{k}=<e_{i(k), 1}, e_{i(k), 2}, \ldots, e_{i(k), j}, \ldots, e_{i(k), m}>
$$

where:

- $\mathrm{m}$ is the number of decision-making areas $\mathrm{OD}_{\mathrm{j}}$ at the relevant decision problem $\mathrm{PD}$, and $\mathrm{Q}\left(\mathrm{D}_{\mathrm{k}}\right)$ is a value of complex decision $D_{k}$, calculated for all of decision-making areas $\mathrm{OD}_{\mathrm{j}}$ according to the formula:

$\mathrm{Q}\left(\mathrm{D}_{\mathrm{k}}\right)=\Sigma \mathrm{e}_{\mathrm{i}(\mathrm{k}), \mathrm{j}} *\left(1+\mathrm{V}_{\mathrm{j}}\right)$

- then for all complex decisions $D_{k}$, in proportion to the fixed value of the decision $\mathrm{Q}\left(\mathrm{D}_{\mathrm{k}}\right)$, according to the formula (2d), are calculated vectors of normalization values $\mathrm{V}_{\mathrm{k}}$, where $\mathrm{v}_{\mathrm{i}(\mathrm{k}) \mathrm{j}}$ is the value calculated for all $\mathrm{OD}_{\mathrm{j}}$ according to the formula (2f) and $k$ is an index of the complex decision $D_{k}$ in question,

$\mathrm{V}_{\mathrm{k}}=<\mathrm{v}_{\mathrm{i}(\mathrm{k}), 1}, \mathrm{v}_{\mathrm{i}(\mathrm{k}), 2}, \ldots, \mathrm{v}_{\mathrm{i}(\mathrm{k}) \mathrm{j}}, \ldots, \mathrm{v}_{\mathrm{i}(\mathrm{k}), \mathrm{m}}>$

where: $v_{i(k), j}$ is the value calculated for all $\mathrm{OD}_{\mathrm{j}}$ according to the formula:

$$
\mathrm{V}_{\mathrm{i}(\mathrm{k}), \mathrm{j}}=\mathrm{e}_{\mathrm{i}(\mathrm{k}) \mathrm{j}} *\left(1+\mathrm{V}_{\mathrm{j}}\right) / \mathrm{Q}\left(\mathrm{D}_{\mathrm{k}}\right)
$$

- calculating $\mathrm{V}_{\mathrm{i}(\mathrm{k}) \mathrm{j}}$ according to the formula (2f) we bring the weight of the significance of the elementary decision $\mathrm{e}_{\mathrm{i}(\mathrm{k}), \mathrm{j}}$ within each $\mathrm{OD}_{\mathrm{j}}$ to normalization:

$$
\Sigma \mathrm{v}_{\mathrm{i}(\mathrm{k}), \mathrm{j}}=\mathrm{v}_{\mathrm{i}(\mathrm{k}), 1}+\mathrm{v}_{\mathrm{i}(\mathrm{k}), 2}+\ldots+\mathrm{v}_{\mathrm{i}(\mathrm{k}), \mathrm{m}}=1
$$

Illustration of the above-described two different standardization procedures are two structurally different examples of calculation model shown in Fig. $2 \mathrm{a}$ and Table 2a, which included a description of a flat decision-making problem PPD with three areas of decision-making: $\mathrm{OD}_{1}, \mathrm{OD}_{2}, \mathrm{OD}_{3}$ and the corresponding large scales significance $\mathrm{V}_{1}=0.2, \mathrm{~V}_{2}$ $=0.3, \mathrm{~V}_{3}=0.5$, each containing three elementary decisions and corresponding lower weight of significance included in the Table $2 \mathrm{a}$ and $2 \mathrm{~b}$. Indexes point to a further complex decisions $D_{k}$.

Table $2 b$ shows the process of normalization of the four complex decisions $D_{k}$ (see Fig. 2a).

For the sake of simplicity, and for better results comparable assumed that the initial value of each elementary decision $e_{i, j}=1,2,3$ or 5 in each of the three decision areas $\mathrm{OD}_{\mathrm{j}}$.

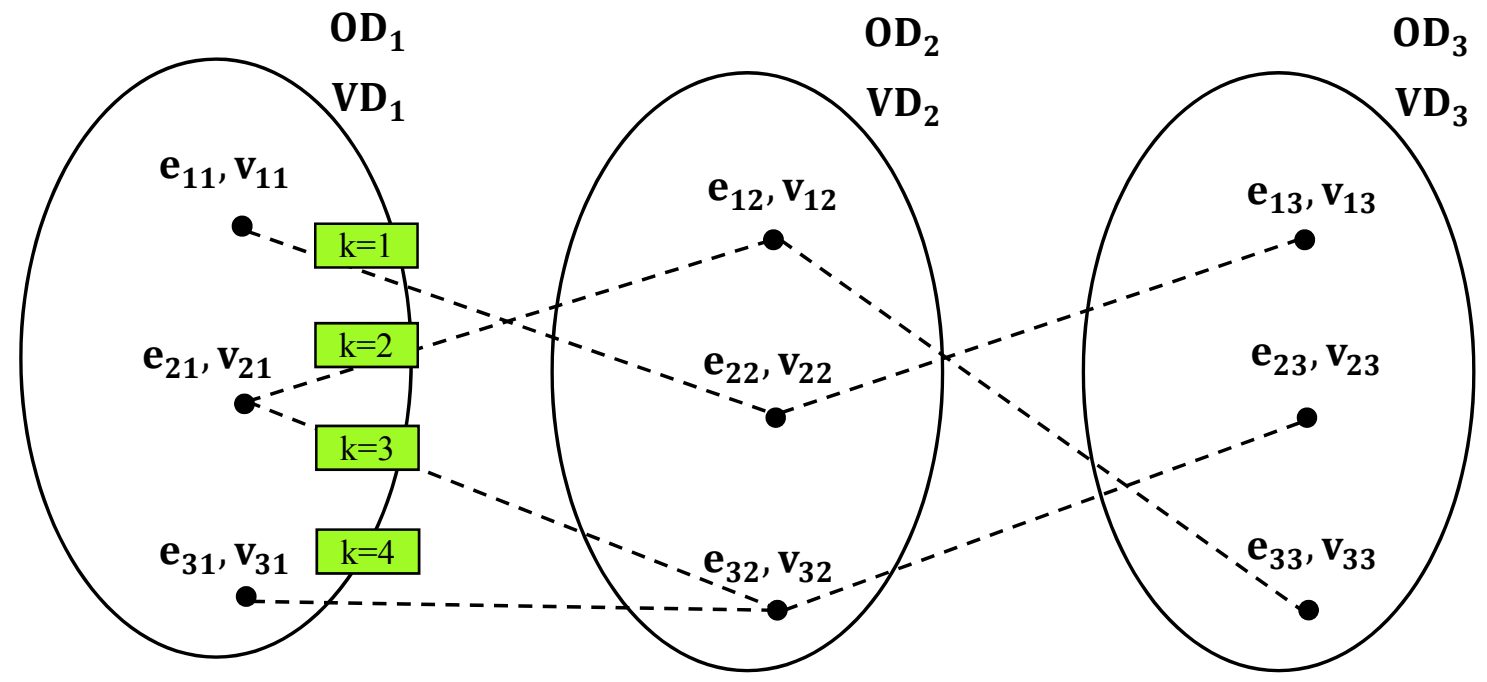

Figure 2a. An example of flat decision problem (FPD), which values $e_{i, j}, v_{i, j}$ and $e_{i(k), j}, v_{i(k), j}$ are set out in the Table $2 \mathrm{a}$ and $2 \mathrm{~b}$ 
The situation shown in Fig. 2a corresponds to set formulas of values $Q\left(D_{k}\right)$ stored in the formula $(2 h)$ and to the value of decisions $\mathrm{Q}\left(\mathrm{D}_{\mathrm{k}}\right)$ stored in the formula (2i).

$$
\begin{aligned}
& \mathrm{Q}\left(\mathrm{D}_{1}\right)=\mathrm{e}_{1,1} *\left(1+\mathrm{V}_{1}\right)+\mathrm{e}_{2,2} *\left(1+\mathrm{V}_{2}\right)+\mathrm{e}_{1,3} *\left(1+\mathrm{V}_{3}\right) \\
& \mathrm{Q}\left(\mathrm{D}_{2}\right)=\mathrm{e}_{2,1} *\left(1+\mathrm{V}_{1}\right)+\mathrm{e}_{1,2} *\left(1+\mathrm{V}_{2}\right)+\mathrm{e}_{3,3} *\left(1+\mathrm{V}_{3}\right) \\
& \mathrm{Q}\left(\mathrm{D}_{3}\right)=\mathrm{e}_{2,1} *\left(1+\mathrm{V}_{1}\right)+\mathrm{e}_{3,2} *\left(1+\mathrm{V}_{2}\right)+\mathrm{e}_{2,3} *\left(1+\mathrm{V}_{3}\right) \\
& \mathrm{Q}\left(\mathrm{D}_{4}\right)=\mathrm{e}_{3,1} *\left(1+\mathrm{V}_{1}\right)+\mathrm{e}_{3,2} *\left(1+\mathrm{V}_{2}\right)+\mathrm{e}_{2,3} *\left(1+\mathrm{V}_{3}\right) \\
& \mathrm{Q}\left(\mathrm{D}_{1}\right)=1 *(1+0.2)+2 *(1+0.3)+2 *(1+0.5)=6.8 \\
& \mathrm{Q}\left(\mathrm{D}_{2}\right)=1 *(1+0.2)+1 *(1+0.3)+2 *(1+0.5)=5.5 \\
& \mathrm{Q}\left(\mathrm{D}_{3}\right)=1 *(1+0.2)+2 *(1+0.3)+1 *(1+0.5)=5.3 \\
& \mathrm{Q}\left(\mathrm{D}_{4}\right)=3 *(1+0.2)+2 *(1+0.3)+2 *(1+0.5)=9.2
\end{aligned}
$$

\begin{tabular}{|c|c|c|c|c|c|c|}
\hline [1] & [2] & [3] & [4] & [5] & [6] & [7] \\
\hline$e_{i, j}$ & - & $\mathrm{v}_{\mathrm{i}, \mathrm{j}}$ & $\mathrm{Vj}$ & {$[2] *[4]$} & {$[5] / \sum[5]$} & {$[2] *(1+[6])$} \\
\hline$e_{1,1}$ & 1 & $1 / 5$ & \multirow{3}{*}{0.2} & $1 * 0.2=0.2$ & $0.2 / 1=0.2$ & $1 *(1+0.2)=1.2$ \\
\hline$e_{2,1}$ & 1 & $1 / 5$ & & $1 * 0.2=0.2$ & $0.2 / 1=0.2$ & $1 *(1+0.2)=1.2$ \\
\hline$e_{3,1}$ & 3 & $3 / 5$ & & $3 * 0.2=0.6$ & $0.6 / 1=0.6$ & $3 *(1+0.6)=4.8$ \\
\hline$\Sigma$ & 5 & 1 & & 1.0 & 1.0 & 7.2 \\
\hline $\mathrm{e}_{1,2}$ & 1 & $1 / 5$ & \multirow{3}{*}{0.3} & $1 * 0.3=0.3$ & $0.3 / 1.5=0.2$ & $1 *(1+0.2)=1.2$ \\
\hline $\mathrm{e}_{2,2}$ & 2 & $2 / 5$ & & $2 * 0.3=0.6$ & $0.6 / 1.5=0.4$ & $2 *(1+0.4)=2.8$ \\
\hline$e_{3,2}$ & 2 & $2 / 5$ & & $2 * 0.3=0.6$ & $0.6 / 1.5=0.4$ & $2 *(1+0.4)=2.8$ \\
\hline$\sum$ & 5 & 1 & & 1.5 & 1.0 & 6.8 \\
\hline$e_{1,3}$ & 2 & $2 / 5$ & \multirow{3}{*}{0.5} & $2 * 0.5=1.0$ & $1.0 / 2.5=0.4$ & $2 *(1+0.4)=2.8$ \\
\hline$e_{2,3}$ & 1 & $1 / 5$ & & $1 * 0.5=0.5$ & $0.5 / 2.5=0.2$ & $1 *(1+0.2)=1.2$ \\
\hline$e_{3,3}$ & 2 & $2 / 5$ & & $2 * 0.5=1.0$ & $1.0 / 2,5=0.4$ & $2 *(1+0.4)=2.8$ \\
\hline$\Sigma$ & 5 & 1 & & 2.5 & 1.0 & 6.8 \\
\hline$\sum$ & 15 & 3 & 1.0 & 5.00 & 3.00 & 20.8 \\
\hline
\end{tabular}

Table 2a. An example of standardization elementary decision $\mathrm{e}_{\mathrm{i}, \mathrm{j}}$ shown in Fig. 2a 
Table $2 b$. An example of normalization of four complex decisions $D_{k}$ shown in Fig. 2a, which in practical applications weight of significance can be expressed in different units, for example $\mathrm{V}_{\mathrm{j}}=100 \%, \mathrm{v}_{\mathrm{i}, \mathrm{j}}=100 \mathrm{~kg}$

\begin{tabular}{|c|c|c|c|c|c|c|c|c|c|}
\hline$[1]$ & [2] & {$[3]$} & {$[4]$} & {$[5]$} & {$[6]$} & $\mathrm{k}=1$ & $\mathrm{k}=2$ & $\mathrm{k}=3$ & $\mathrm{k}=4$ \\
\hline$e_{i, j}$ & - & $\mathrm{v}_{\mathrm{i}, \mathrm{j}}$ & $\mathrm{k}$ & $\mathrm{V}_{\mathrm{j}}$ & {$[2] *[5]$} & $\begin{array}{c}{[6] /} \\
\sum[6,1] \\
\end{array}$ & $\begin{array}{c}{[6] /} \\
\sum[6,2] \\
\end{array}$ & $\begin{array}{c}{[6] /} \\
\sum[6,3]\end{array}$ & $\begin{array}{c}{[6] /} \\
\sum[6,4]\end{array}$ \\
\hline $\mathrm{e}_{1,1}$ & 1 & $1 / 5$ & 1 & \multirow{3}{*}{0.2} & $1 * 0.2=0.2$ & 0.2 & & & \\
\hline$e_{2,1}$ & 1 & $1 / 5$ & 2,3 & & $1 * 0.2=0.2$ & & 0.2 & 0.2 & \\
\hline $\mathrm{e}_{3,1}$ & 3 & $3 / 5$ & 4 & & $3 * 0.2=0.6$ & & & & 0.6 \\
\hline$\sum$ & 5 & 1.0 & & & 1.0 & & & & \\
\hline $\mathrm{e}_{1,2}$ & 1 & $1 / 5$ & 2 & \multirow{3}{*}{0.3} & $1 * 0.3=0.3$ & & 0.3 & & \\
\hline $\mathrm{e}_{2,2}$ & 2 & $2 / 5$ & 1 & & $2 * 0.3=0.6$ & 0.6 & & & \\
\hline $\mathrm{e}_{3,2}$ & 2 & $2 / 5$ & 3,4 & & $2 * 0.3=0.6$ & & & 0.6 & 0.6 \\
\hline$\sum$ & 5 & 1.0 & & & 1.5 & & & & \\
\hline $\mathrm{e}_{1,3}$ & 2 & $2 / 5$ & 1 & \multirow{3}{*}{0.5} & $2 * 0.5=1.0$ & 1.0 & & & \\
\hline$e_{2,3}$ & 1 & $1 / 5$ & 3,4 & & $1 * 0.5=0.5$ & & & 0.5 & 0.5 \\
\hline $\mathrm{e}_{3,3}$ & 2 & $2 / 5$ & 2 & & $2 * 0.5=1.0$ & & 1.0 & & \\
\hline$\sum$ & 5 & 1.0 & & & 2.5 & & & & \\
\hline$\sum$ & 15 & 3.0 & & 1.0 & 5.0 & 1.8 & 1.5 & 1.3 & 1.7 \\
\hline
\end{tabular}

\section{The two-layer hierarchical decision problem}

Presented in Fig. 1a data of strategic decisionmaking problem $\mathrm{PD}^{\mathrm{S}}$ have been recorded in the form of Table 1a, in which the value of each strategic elementary decision is determined a priori, or is determined by the solution of tactical decision problem, as shown in Fig. 3a (see Table 3a).

In every area of decision-making $\mathrm{OD}_{\mathrm{j}}$, on all layers of decision problems (strategic, tactical and operational), the square indicated the currently taken (fixed) elementary decisions indicating their participation in the areas of decision-making, contained in the layers of decision-making problems (see Fig. 1a and Fig. 3a).

Fig. $3 \mathrm{a}$ is an example of a 2-level decision-making problem which is the development of a strategic decision problem $\mathrm{PD}^{\mathrm{S}}$ shown in Fig. 1a. In this case, the tactical decision problem $\mathrm{PD}^{\mathrm{T}}$ and its three tactical decision-making areas $\mathrm{OD}_{1}{ }^{\mathrm{T}}, \mathrm{OD}_{2}{ }^{\mathrm{T}}$, and $\mathrm{OD}_{3}{ }^{\mathrm{T}}$ are used to determine, for example, only three elementary decisions $\mathrm{e}_{1}{ }^{\mathrm{S}}, \mathrm{e}_{2}{ }^{\mathrm{S}}$ and $\mathrm{e}_{3}{ }^{\mathrm{S}}$ and generates eight possible options (see Table 3a). 


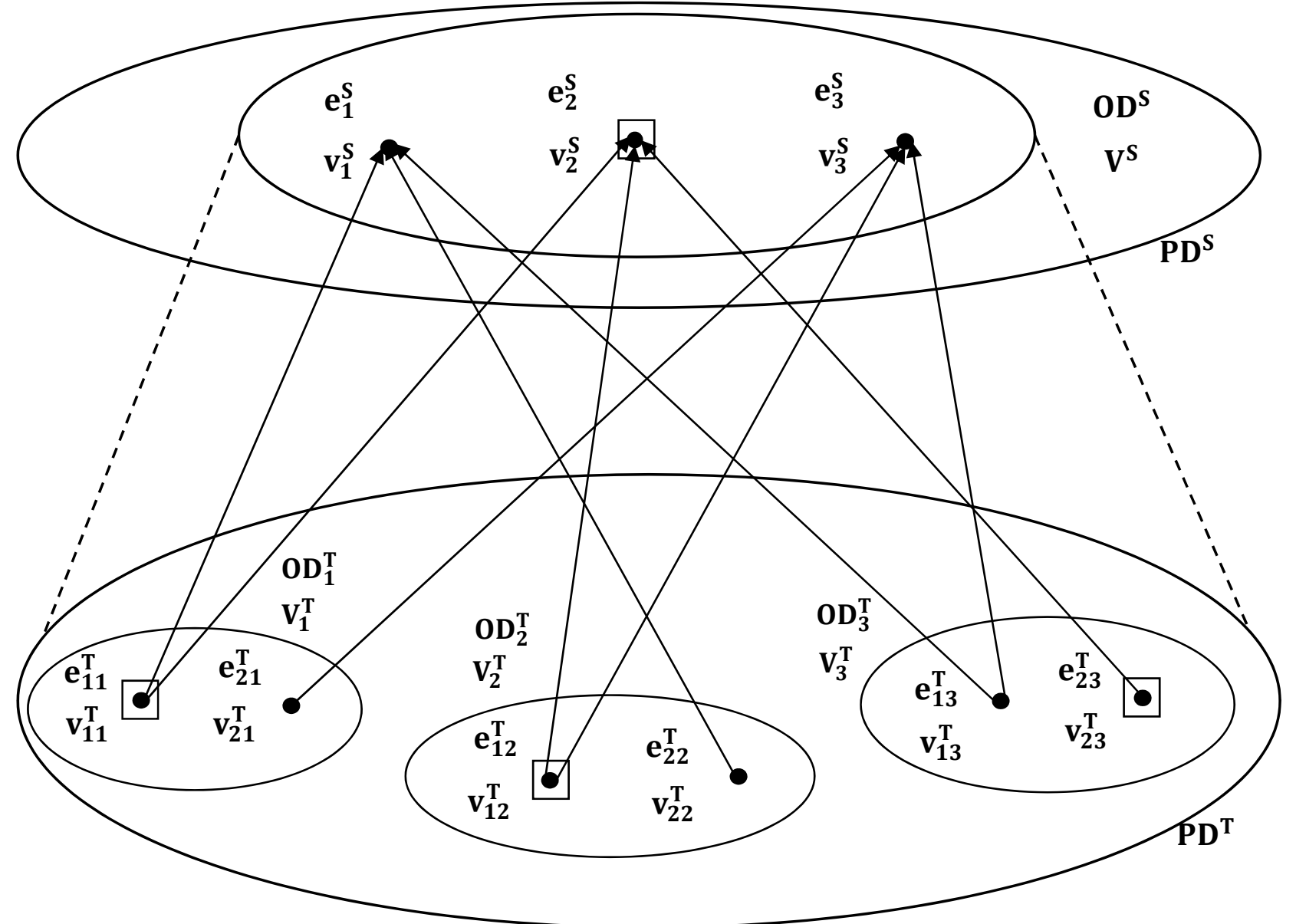

Figure 3a. An example of 2-layer hierarchical problem, in which the elementary decision $\mathrm{e}_{i}^{\mathrm{S}}$ of strategic layers are estimated on the basis of elementary decision $e_{i, j}{ }^{\top}$ originated from three tactical decision-making areas

( $\square$ - current decision)

In this case please note that the maximum number of elementary decisions in the area of strategic decision-making $\mathrm{PD}^{\mathrm{S}}$, called the power of decisionmaking area $\left|\mathrm{PD}^{\mathrm{S}}\right|$, is obtained by multiplying power of all tactical decision-making areas of tactical decision-making problem $\mathrm{PD}^{\mathrm{T}}$ and in the example is:

$$
\left|\mathrm{OD}_{1}{ }^{\mathrm{T}}\right| *\left|\mathrm{OD}_{2}^{\mathrm{T}}\right| *\left|\mathrm{OD}_{3}{ }^{\mathrm{T}}\right|=8
$$

Table $3 \mathrm{a}$ shows the eight potentially possible elementary decision $e_{i}^{S}$ of strategic area of decisionmaking $\mathrm{OD}^{\mathrm{S}}$ obtained as the sum of the products of the importance of their constituent elementary decision $\mathrm{e}_{\mathrm{i}, \mathrm{j}}{ }^{\mathrm{T}}$ obtained from the tactical decisionmaking areas $\mathrm{OD}_{1}{ }^{\mathrm{T}}, \mathrm{OD}_{2}{ }^{\mathrm{T}}, \mathrm{OD}_{3}{ }^{\mathrm{T}}$ and modified by values of significance $\mathrm{v}_{\mathrm{i}, \mathrm{j}}{ }^{\mathrm{T}}$ of these elementary decisions.
Such a situation is possible if between pairs of elementary decision $e_{i, j}{ }^{\mathrm{T}}$ from different tactical decision-making areas $\mathrm{OD}_{\mathrm{j}}^{\mathrm{T}}$, there is no insurmountable contradiction \# (with a value of \# = 1), for example, for a forgotten elementary strategic decision $e_{6} S$ (highlighted in green in the Table 3a).

The reason for the exclusion decision $\mathrm{e}_{6}{ }^{\mathrm{S}}$ is the presence in layer $\mathrm{T}$ of a two elementary tactical decisions which contradict one another

$$
\#<\mathrm{e}_{2,1}{ }^{\mathrm{T}}: \mathrm{e}_{2,2}{ }^{\mathrm{T}}>=0.3
$$

connected in Fig. 4a with red dashed line.

In Table 3a yellow color distinguishes three strategic elementary decisions $\mathrm{e}_{1}{ }^{\mathrm{S}}, \mathrm{e}_{2}{ }^{\mathrm{S}}$ and $\mathrm{e}_{3} \mathrm{~S}$, from which is currently implemented only elementary decision $\mathrm{e}_{2} \mathrm{~S}$. 
Table $3 \mathrm{a}$. The values of the elementary strategic decision $\mathrm{e}_{i}^{\mathrm{S}}$ obtained as the sum of the products of their constituent tactical elementary decisions $\mathrm{e}_{\mathrm{i}, \mathrm{j}}{ }^{\mathrm{T}}$, obtained from the tactical decision-making areas $\mathrm{OD}_{1}{ }^{\mathrm{T}}, \mathrm{OD}_{2}{ }^{\mathrm{T}}, \mathrm{OD}_{3}^{\mathrm{T}}$

\begin{tabular}{|l|l|}
\hline $\mathrm{e}_{1}{ }^{\mathrm{S}}=\mathrm{e}_{1,1}{ }^{\mathrm{T}} * \mathrm{~V}_{1}{ }^{\mathrm{T}}+\mathrm{e}_{2,2}{ }^{\mathrm{T}} * \mathrm{~V}_{2}{ }^{\mathrm{T}}+\mathrm{e}_{1,3}{ }^{\mathrm{T}} * \mathrm{~V}_{3}{ }^{\mathrm{T}}$ & $\mathrm{e}_{5}{ }^{\mathrm{S}}=\mathrm{e}_{2,1}{ }^{\mathrm{T}} * \mathrm{~V}_{1}{ }^{\mathrm{T}}+\mathrm{e}_{2,2}{ }^{\mathrm{T}} * \mathrm{~V}_{2}{ }^{\mathrm{T}}+\mathrm{e}_{2,3}{ }^{\mathrm{T}} * \mathrm{~V}_{3}{ }^{\mathrm{T}}$ \\
\hline $\mathrm{e}_{2}{ }^{\mathrm{S}}=\mathrm{e}_{1,1}{ }^{\mathrm{T}} * \mathrm{~V}_{1}{ }^{\mathrm{T}}+\mathrm{e}_{1,2}{ }^{\mathrm{T}} * \mathrm{~V}_{2}{ }^{\mathrm{T}}+\mathrm{e}_{2,3}{ }^{\mathrm{T}} * \mathrm{~V}_{3}{ }^{\mathrm{T}}$ & $\mathrm{e}_{6}{ }^{\mathrm{S}}=\mathrm{e}_{2,1}{ }^{\mathrm{T}} * \mathrm{~V}_{1}{ }^{\mathrm{T}}+\mathrm{e}_{2,2}{ }^{\mathrm{T}} * \mathrm{~V}_{2}{ }^{\mathrm{T}}+\mathrm{e}_{1,3}{ }^{\mathrm{T}} * \mathrm{~V}_{3}{ }^{\mathrm{T}}$ \\
\hline $\mathrm{e}_{3}{ }^{\mathrm{S}}=\mathrm{e}_{2,1}{ }^{\mathrm{T}} * \mathrm{~V}_{1}{ }^{\mathrm{T}}+\mathrm{e}_{1,2}{ }^{\mathrm{T}} * \mathrm{~V}_{2}{ }^{\mathrm{T}}+\mathrm{e}_{1,3}{ }^{\mathrm{T}} * \mathrm{~V}_{3}{ }^{\mathrm{T}}$ & $\mathrm{e}_{7}{ }^{\mathrm{S}}=\mathrm{e}_{2,1}{ }^{\mathrm{T}} * \mathrm{~V}_{1}{ }^{\mathrm{T}}+\mathrm{e}_{1,2}{ }^{\mathrm{T}} * \mathrm{~V}_{2}{ }^{\mathrm{T}}+\mathrm{e}_{2,3}{ }^{\mathrm{T}} * \mathrm{~V}_{3}{ }^{\mathrm{T}}$ \\
\hline $\mathrm{e}_{4}{ }^{\mathrm{S}}=\mathrm{e}_{1,1}{ }^{\mathrm{T}} * \mathrm{~V}_{1}{ }^{\mathrm{T}}+\mathrm{e}_{1,2}{ }^{\mathrm{T}} * \mathrm{~V}_{2}{ }^{\mathrm{T}}+\mathrm{e}_{1,3}{ }^{\mathrm{T}} * \mathrm{~V}_{3}{ }^{\mathrm{T}}$ & $\mathrm{e}_{8}{ }^{\mathrm{S}}=\mathrm{e}_{1,1}{ }^{\mathrm{T}} * \mathrm{~V}_{1}{ }^{\mathrm{T}}+\mathrm{e}_{2,2}{ }^{\mathrm{T}} * \mathrm{~V}_{2}{ }^{\mathrm{T}}+\mathrm{e}_{2,3}{ }^{\mathrm{T}} * \mathrm{~V}_{3}{ }^{\mathrm{T}}$ \\
\hline
\end{tabular}

Decisions highlighted in the strategic layer $\mathrm{S}$ are set out in Table 3a through tactical elementary decisions

$$
\mathrm{e}_{1,1}{ }^{\mathrm{T}}, \mathrm{e}_{1,2}{ }^{\mathrm{T}}, \mathrm{e}_{1,3}{ }^{\mathrm{T}}, \mathrm{e}_{2,1}{ }^{\mathrm{T}}, \mathrm{e}_{2,2}{ }^{\mathrm{T}}, \mathrm{e}_{2,3}{ }^{\mathrm{T}}
$$

and relevance $\mathrm{v}_{\mathrm{i}, \mathrm{j}}{ }^{\mathrm{T}}$ of these decisions.

Changing the current strategic elementary decisions $\mathrm{e}_{2}{ }^{\mathrm{S}}$ on another elementary decision $\mathrm{e}_{1}{ }^{\mathrm{S}}$ is possible if the anticipated changes will take place

$$
\mathrm{e}_{1,2}{ }^{\mathrm{T}} \rightarrow \mathrm{e}_{2,2}{ }^{\mathrm{T}} \& \mathrm{e}_{2,3}{ }^{\mathrm{T}} \rightarrow \mathrm{e}_{1,3}{ }^{\mathrm{T}}
$$

Changing the current strategic elementary decisions $\mathrm{e}_{2}{ }^{\mathrm{S}}$ on another elementary decision $\mathrm{e}_{3}{ }^{\mathrm{S}}$ is possible if the anticipated changes will take place

$$
\mathrm{e}_{1,1}{ }^{\mathrm{T}} \rightarrow \mathrm{e}_{2,1}{ }^{\mathrm{T}} \& \mathrm{e}_{2,3}{ }^{\mathrm{T}} \rightarrow \mathrm{e}_{1,3}{ }^{\mathrm{T}}
$$

In the process of decision-making it is necessary to evaluating their significance from the point of view of costs (losses) versus the expected benefits.
Valuation takes into account normalizing action of large scales of relevance $V_{j}$ for the elementary decision $e_{i(k), j}$ belonging to the complex decision $D_{k}$ of the decision-making areas $\mathrm{OD}_{\mathrm{j}}$ and normalizing action of significance weights $\mathrm{v}_{\mathrm{i}(\mathrm{k}) \mathrm{j}}$ for elementary decisions $\mathrm{e}_{\mathrm{i}(\mathrm{k}), \mathrm{j}}$ presented in the Chapter 2 .

The relative weight $\mathrm{V}_{\mathrm{k}}$ of the significance of a single complex operational decision $\mathrm{D}_{\mathrm{k}}{ }^{\mathrm{O}}$ or a single complex tactical decision $\mathrm{D}_{\mathrm{k}}{ }^{\mathrm{T}}$, considered with decision problem, is calculated from the formula (3a) as the sum of the products of the weights significance of decision-making areas $\mathrm{V}_{j}^{\mathrm{O} / \mathrm{T}}$ and weights of elementary significance $\mathrm{v}_{\mathrm{i}(\mathrm{k}), \mathrm{j}}$ / $\mathrm{T}$ of the decision of the corresponding decision-making areas:

$$
\mathrm{Q}\left(\mathrm{D}_{\mathrm{k}}{ }^{\mathrm{O} / \mathrm{T}}\right)=\sum \mathrm{V}_{\mathrm{j}}^{\mathrm{O} / \mathrm{T}} * \mathrm{~V}_{\mathrm{i}(\mathrm{k}), \mathrm{j}}^{\mathrm{O} / \mathrm{T}}
$$

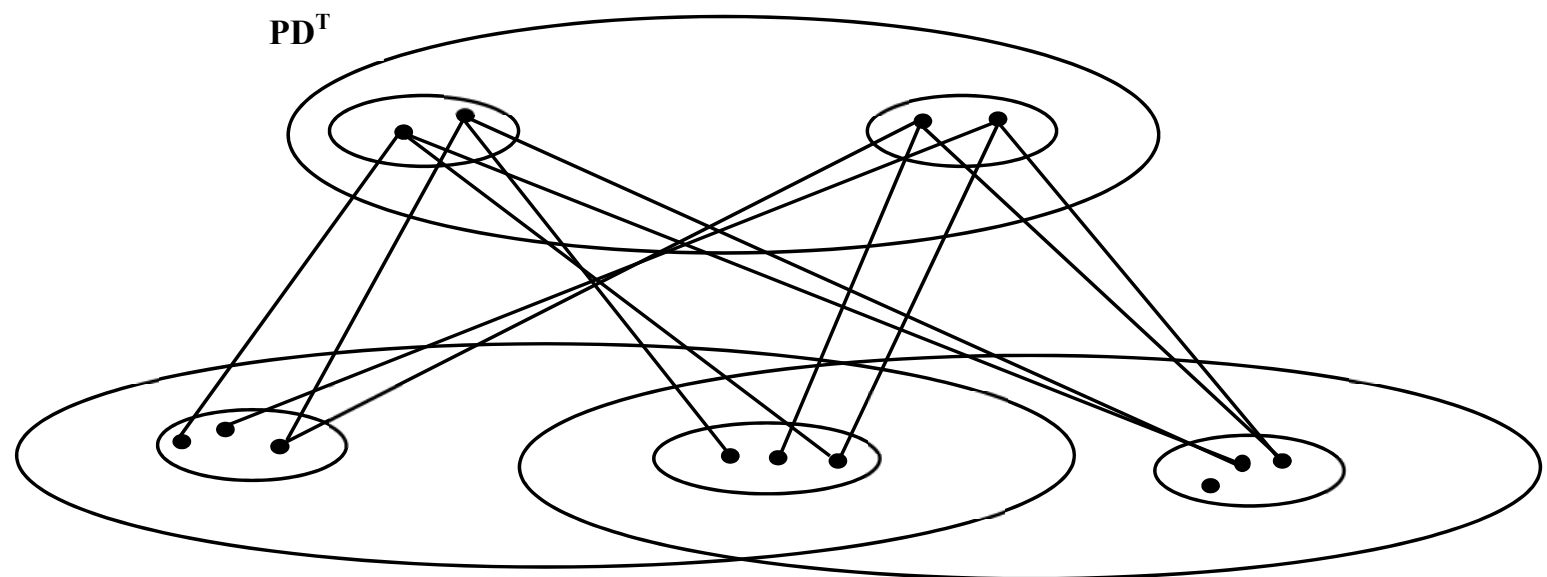

Figure. 3b. Example of the three decision problems in a hierarchical structure: $\mathrm{PD}^{\mathrm{T}}$ - parent tactical decision problem, $\mathrm{PD}_{1}{ }^{\mathrm{O}}, \mathrm{PD}_{2}{ }^{\mathrm{O}}$ - operational problems with the common area of decision-making labeled as $\mathrm{OD}_{2,1}{ }^{\mathrm{O}}, \mathrm{OD}_{1,2} \mathrm{O}$ 
Valuing the decision problems focuses on three operations:

- evaluating the significance of decision-making areas $\mathrm{Vj}$,

- evaluation of elementary decision $\mathrm{e}_{\mathrm{i}(\mathrm{k}) \mathrm{j}}$ and their significance $\mathrm{V}_{\mathrm{i}(\mathrm{k}) \mathrm{j}}$,

- estimating of contradictions \# in pairs of elementary decisions included in the decision $\mathrm{D}_{\mathrm{k}}$.

Valuing the decisions resulting in the problems of hierarchical decision-making process becomes especially complicated if you allow the possibility of partial or full overlapping of decision-making areas, belonging to different HPD shown in Fig. 3b.

\section{A priori contradictions of an elementary decisions in decision-making problems}

A priori of contradictions due to a particularly frequently occurring variable phenomena in the decision-making processes. Their solution is related to the issue of neutralization or liquidation of contradictions. In some cases, emerging of contradictions of varying severity is a serious obstacle in maintain- ing the continuity of the operation of the organizational and technical, and in particular systems of critical infrastructure.

Fig. 4a illustrates a tactical decision problem moved from the two-layer hierarchical problem shown in Fig. 3a. The dashed blue line connecting the two pairs of elementary tactical decisions remain internally in absolute of contradictions - which is denoted by the expression:

$$
\#<\mathrm{e} 2,1 \mathrm{~T}: \mathrm{e} 2,3 \mathrm{~T}>=1, \quad \#<\mathrm{e} 1,2 \mathrm{~T}: \mathrm{e} 2,3 \mathrm{~T}>=1
$$

This means that none of the pairs can be used to construct and make decision on strategic layer. Whereas a red line indicates a pair of elementary tactical decision:

$$
\#<\mathrm{e} 2,1 \mathrm{~T}: \mathrm{e} 2,2 \mathrm{~T}>=0.3
$$

remaining internally fuzzy of contradictions - which means that it can be used to construct and take additional fourth elementary strategic decision $\mathrm{e}_{6}{ }^{\mathrm{S}}$ provided incur costs due to the removal of the obstacles inherent in the indicated pair of elementary tactical decisions.

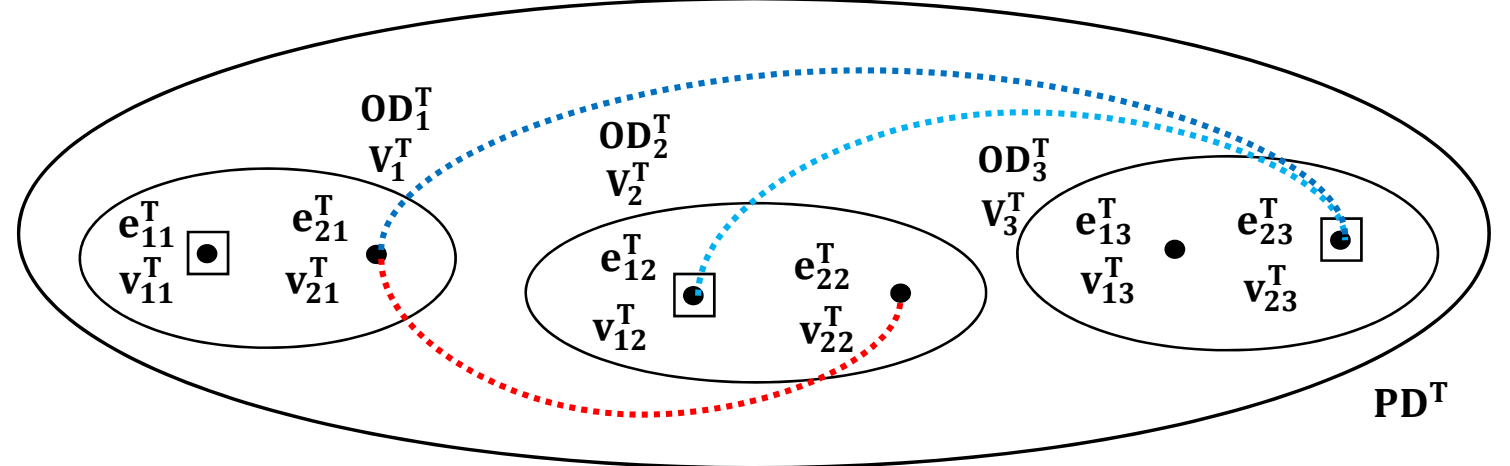

Figure 4a. An example of a tactical decision problem in which a pair of elementary decision $\#<e_{2,1}{ }^{\mathrm{T}}: \mathrm{e}_{2,2}{ }^{\mathrm{T}}>=0.3$ a priori contradicts and can be used to produce an additional elementary decision in a strategic layer

It should be noted (see Fig. 4a), that in case of elementary strategic decision $\mathrm{e}_{6}{ }^{\mathrm{S}}$ the other two pairs $\#<\mathrm{e}_{2,1}{ }^{\mathrm{T}}: \mathrm{e}_{1,3}{ }^{\mathrm{T}}>$ and $\#<\mathrm{e}_{2,2}{ }^{\mathrm{T}}: \mathrm{e}_{1,3}{ }^{\mathrm{T}}>$ remain in the relationship \# $=0$, which means that they do not cause additional costs.

In the case under consideration issues of contradictions of elementary decisions we assume that the relative weighting of the significance of a single complex decision $D_{k}$ is calculated as the sum of the products of the weights of significance areas of decision-making $\mathrm{V}_{\mathrm{j}}$ and of elementary decisions $\mathrm{e}_{\mathrm{i}(\mathrm{k}) \mathrm{j}}$ from the corresponding areas of decision-making according to the formula:

$$
\mathrm{Q}\left(\mathrm{D}_{\mathrm{k}}\right)=\sum \mathrm{e}_{\mathrm{i}(\mathrm{k}) \mathrm{j}} * \mathrm{~V}_{\mathrm{j}}
$$

where for each index $\mathrm{i}$ from the area of decisionmaking $D_{j}$, the value of the index $j$ for all of elementary decisions $\mathrm{e}_{\mathrm{i}(\mathrm{k}) \mathrm{j}}$ belonging to the decision $\mathrm{D}_{\mathrm{k}}$ from the decision-making areas $\mathrm{D}_{\mathrm{j}}$. 
In some applications for the evaluation of internal contradictions form (value), the elementary decision $e_{i(k), j}$ may be converted into the weight of significance $\mathrm{v}_{\mathrm{i}(\mathrm{k}) \mathrm{j}}$.

A contradiction on the scale [0..1]

$$
\#<\mathrm{e}_{\mathrm{i}, 1}: \mathrm{e}_{\mathrm{i}, 2}: \ldots: \mathrm{e}_{\mathrm{i}, \mathrm{j}}: \ldots: \mathrm{e}_{\mathrm{i}, \mathrm{m}}>
$$

is characteristic of relations between elementary decisions $e_{i, j} \in O D_{j}$, belonging to pairs of different areas of decision-making $\mathrm{OD}_{\mathrm{j}}$ is characterized by a synergistically correlated increase in its value, dependent on the number of elementary decision $e_{i, j}$ being simultaneously the subject of contradiction, which may significantly affect the value of the final decision $\mathrm{Q}\left(\mathrm{D}_{\mathrm{k}}\right)$.

The $Q\left(D_{k}\right)$ value for the conflict \#>0 is calculated for a complex decision $\mathrm{D}_{\mathrm{k}}$ according to the formula:

$$
\mathrm{Q}^{\#}\left(\mathrm{D}_{\mathrm{k}}\right)=\mathrm{Q}\left(\mathrm{D}_{\mathrm{k}}\right) *\left(1+\#\left\{\mathrm{e}_{\mathrm{i}(\mathrm{k}), 1}, \mathrm{e}_{\mathrm{i}(\mathrm{k}), 2}, \ldots, \mathrm{e}_{\mathrm{i}(\mathrm{k}), \mathrm{m}}\right\}\right)
$$

In further discussion, the calculation of contradiction \# is conducted only in relation to the value $e_{i, j}$ and $\mathrm{V}_{\mathrm{j}}$ and their standardized form. The contradiction is calculated according to the general formula for all different pairs \#< $<\mathrm{e}_{\mathrm{j}, \mathrm{p}}: \mathrm{e}_{\mathrm{j}, \mathrm{q}}>$ of $\#<\mathrm{e}_{\mathrm{i}, 1}: \mathrm{e}_{\mathrm{i}, 2}: \ldots: \mathrm{e}_{\mathrm{i}, \mathrm{j}}: \ldots$ $: \mathrm{e}_{\mathrm{i}, \mathrm{m}}>$ as the sum of:

$$
\#<\mathrm{e}_{\mathrm{i}, 1}: \mathrm{e}_{\mathrm{i}, 2}: \ldots: \mathrm{e}_{\mathrm{i}, \mathrm{m}}>=\sum \#<\mathrm{e}_{\mathrm{p}, \mathrm{j}}: \mathrm{e}_{\mathrm{q}, \mathrm{jq}}>
$$

where:

$$
\begin{aligned}
& \mathrm{p}=1 . .(\mathrm{q}-1) ; \mathrm{q}=2 . . \mathrm{m} \\
& \#<\mathrm{e}_{\mathrm{p}, \mathrm{jp}}: \mathrm{e}_{\mathrm{q}, \mathrm{q} q}>=\left[\#\left\{\mathrm{e}_{\mathrm{p}, \mathrm{p}}: \mathrm{e}_{\mathrm{q}, \mathrm{jq}}\right\} /\left(1-\#\left\{\mathrm{e}_{\mathrm{p}, \mathrm{p}}: \mathrm{e}_{\mathrm{q}, \mathrm{j} q}\right\}\right)\right] \\
& *\left[\left(\mathrm{e}_{\mathrm{p}, \mathrm{jp}} * \mathrm{~V}_{\mathrm{jp}}+\mathrm{e}_{\mathrm{q}, \mathrm{jq}} * \mathrm{~V}_{\mathrm{jq}}\right) /\left(\mathrm{V}_{\mathrm{jp}}+\mathrm{V}_{\mathrm{jq}}\right)\right]
\end{aligned}
$$

where:

$\#<e_{\mathrm{p}, \mathrm{p}}: \mathrm{e}_{\mathrm{q}, \mathrm{q} q}-$ value conflict between the elementary decisions $e_{p, j p}, e_{q, j q}$ measured on the scale of [0..1].

For the considered strategic decision $\mathrm{e}_{6}$ :

$$
\begin{aligned}
\mathrm{e}_{6}{ }^{\mathrm{S}}= & \mathrm{e}_{2,1}{ }^{\mathrm{T}} * \mathrm{~V}_{2,1}{ }^{\mathrm{T}} * \mathrm{~V}_{1}{ }^{\mathrm{T}}+\mathrm{e}_{2,2}{ }^{\mathrm{T}} * \mathrm{~V}_{2,2}{ }^{\mathrm{T}} * \mathrm{~V}_{2}{ }^{\mathrm{T}} \\
& +\mathrm{e}_{1,3}{ }^{\mathrm{T}} * \mathrm{~V}_{1,3}{ }^{\mathrm{T}} * \mathrm{~V}_{3}{ }^{\mathrm{T}}
\end{aligned}
$$

assuming that the contradictions in pairs are:

$$
\begin{array}{lll}
\#\left\{\mathrm{e}_{2,1}: \mathrm{e}_{2,2}\right\}=0.3 & \mathrm{e}_{2,1}=1 & \mathrm{~V}_{1}=0.2 \\
\#\left\{\mathrm{e}_{2,2}: \mathrm{e}_{1,3}\right\}=0.0 & \mathrm{e}_{2,2}=2 & \mathrm{~V}_{2}=0.3 \\
\#\left\{\mathrm{e}_{2,1}: \mathrm{e}_{1,3}\right\}=0.0 & \mathrm{e}_{1,3}=3 & \mathrm{~V}_{3}=0.5
\end{array}
$$

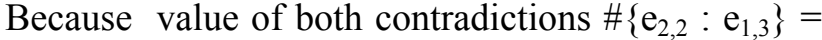
0.0 and $\#\left\{\mathrm{e}_{2,1}: \mathrm{e}_{1,3}\right\}=0.0$ the general pattern $\mathrm{Q}^{\#}\left(\mathrm{D}_{\mathrm{k}}\right)$ change the contradiction $\#<\mathrm{e}_{2,1}: \mathrm{e}_{2,2}: \mathrm{e}_{1,3}>$ form to the contradictions $\#<\mathrm{e}_{2,1}: \mathrm{e}_{2,2}>$.

The conducted calculations show over 17\% increase in the cost of decision $Q^{\#}\left(D_{k}\right)$ due to the value of contradiction \#( $\left.\mathrm{e}_{2,1}: \mathrm{e}_{2,2}\right)$ :

$$
\begin{aligned}
& \mathrm{Q}^{\#}\left(<\mathrm{e}_{2,1}: \mathrm{e}_{2,2}>\right)=\left[\#\left\{\mathrm{e}_{2,1}, \mathrm{e}_{2,2}\right\} /\left(1-\#\left\{\mathrm{e}_{2,1}, \mathrm{e}_{2,2}\right\}\right)\right] \\
& *\left[\left(\mathrm{e}_{2,1} * \mathrm{~V} 1+\mathrm{e}_{2,2} * \mathrm{~V} 2\right) /(\mathrm{V} 1+\mathrm{V} 2)\right] \\
& \mathrm{Q}^{\#}\left(<\mathrm{e}_{2,1}: \mathrm{e}_{2,2}>\right)=[0.3 /(1-0.3)] *[(1 * 0.2+2 * \\
& 0.3) /(0.2+0.3)]=3 / 7 * 0.8 / 0.5=0.17
\end{aligned}
$$

\section{An example of the 3-layer hierarchical model of decision problem}

The final part of the discussion on the merits of decision problems solving is shown at Fig. 5a, where 3-layer decision problem consist of three operating complex decision problems including seven operational decision-making areas.

3-layer decision problem shown at Fig. 5a includes:

- $\mathrm{PD}_{1}{ }^{\mathrm{S}}$ - strategic decision problem which consists of one strategic area of decision-making:

$\mathrm{OD}_{11} \mathrm{~s}$,

- $\mathrm{PD}_{1}{ }^{\mathrm{T}}$ - tactic decision problem which consists of three tactic areas of decision-making:

$\mathrm{OD}_{11}{ }^{\mathrm{T}}, \mathrm{OD}_{21}{ }^{\mathrm{T}}$ and $\mathrm{OD}_{31}{ }^{\mathrm{T}}$,

- $\mathrm{PD}_{1}{ }^{\mathrm{O}}$ - operational decision problems which consists two areas of decision-making:

$\mathrm{OD}_{11}{ }^{\mathrm{O}}$ and $\mathrm{OD}_{21}{ }^{\mathrm{O}}$,

- $\mathrm{PD}_{2}{ }^{\mathrm{O}}$ - operational decision problems which consists two areas of decision-making:

$\mathrm{OD}_{12}{ }^{\mathrm{O}}$ and $\mathrm{OD}_{22}{ }^{\mathrm{O}}$,

- $\mathrm{PD}_{3}{ }^{\mathrm{O}}$ - operational decision problems which consists three areas of decision-making:

$\mathrm{OD}_{13}{ }^{\mathrm{O}}, \mathrm{OD}_{23}{ }^{\mathrm{O}}$ and $\mathrm{OD}_{33}{ }^{\mathrm{O}}$.

In practice, making organizational decisions, irrespective of their place of occurrence, stands out the so-called operational layer, in which elementary decisions do not require solving more specific decision problems, because resources are available and sufficient data to formulate an appropriate set of operating elementary decisions and take the one that will best meet the multi-criteria imposed limitations. 
For the smooth execution of operations analysis and simulation, and to indicate the paths of decisionmaking in the hierarchical structure of decision- making (HSD), it is necessary to replace the signs index, used in Fig. 5a, by digital codes.

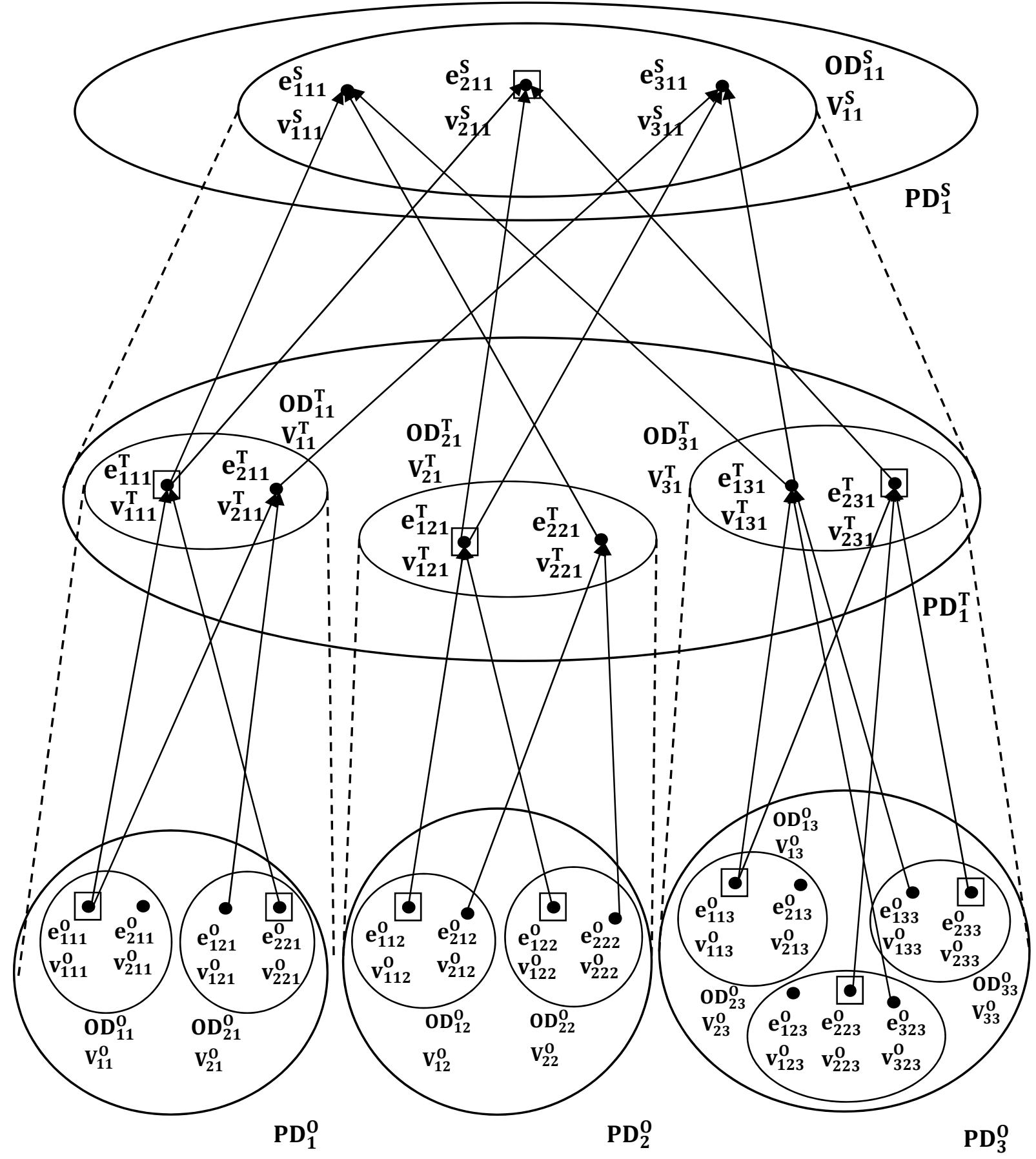

Figure 5a. An example of the problem of three-tier hierarchy, in which 3 of the elementary strategic decisions are estimated on the basis of the 6 elementary tactical decisions and the 15 elementary operational decisions ( $\square$ - current decision) 
This way of encoding is based on assigning the serial numbers of the index components:

- code decision problem is $\mathrm{YZ}$, where $\mathrm{Y}$ is the number of decision-making problem in a layer $\mathrm{Z}$,

- area code decision is $\mathrm{XYZ}$, where $\mathrm{X}$ is the number of decision-making in the area of decision problem YZ,
- code of elementary decision to WXYZ, where $\mathrm{W}$ is the number of elementary decision-making in the area of XYZ.

Coding rules of HSD components are included in Table 5a and the Table 5b.

Table 5a. Rules of coding elements hierarchical decision-making structure (HSD)

\begin{tabular}{|l|c|r|l|}
\hline \multicolumn{1}{|c|}{ element } & $\begin{array}{c}\text { digital code specifying the type } \\
\text { of item and its decision-making } \\
\text { position in the HSD }\end{array}$ & \multicolumn{2}{|c|}{$\begin{array}{c}\text { example of code element } \\
\text { in Fig. 5a }\end{array}$} \\
\hline layer of decision-making & Z & 1 & layer of strategy S \\
\hline decision problem & YZ & 11 & decision problem PD \\
\hline area of decision-making & XYZ & 111 & decision area OD \\
\hline elementary decisions & WXYZ & 2111 & current elementary decision $\mathrm{e}_{211} \mathrm{~S}^{\mathrm{n}}$ \\
\hline
\end{tabular}

In accordance with the principles of digital coding HSD in Table $5 \mathrm{~b}$ has been saved example path for the current elementary decisions $\mathrm{e}_{211} \mathrm{~S}$, leading from the strategic decision-making layers $\mathrm{S}$ - marked with number 1 .
This path has been designated by indicating three elementary decision of tactical layer $\mathrm{T}$ - marked number 2 , and seven elementary decision of operational layer $\mathrm{O}$ - marked with the number 3 - Fig. 5 a.

Table $5 \mathrm{~b}$. The example path for the current decision-making elementary decisions

\begin{tabular}{|c|c|c|c|c|c|c|c|}
\hline layer of decision-making & \multicolumn{7}{|c|}{ decision path for the current elementary decision $\mathrm{e}_{2}^{\mathrm{S}}$ (Fig. 5a) } \\
\hline S - Strategic (1) & \multicolumn{7}{|l|}{2111} \\
\hline T - Tactical (2) & \multicolumn{2}{|c|}{1112} & \multicolumn{2}{|l|}{1212} & \multicolumn{3}{|l|}{2312} \\
\hline O - Operating (3) & 1113 & 2213 & 1123 & 1223 & 1133 & 2233 & 2333 \\
\hline
\end{tabular}

\section{Summary}

The condition for the effectiveness of decisionmaking processes is to spread out the so-called competence network over the cells of the organizational structure in the form of a hierarchy of problems and decision-making areas.

Each of the competence network should include: collections of significance of individual areas of decision-making $\left\{\mathrm{V}^{\mathrm{OD}}\right\}$, stock significance $\left\{\mathrm{V}_{\mathrm{i}, \mathrm{j}}\right\}$ of elementary decisions $e_{i, j}$ and sets of a priori conflicts occurring between pairs of elementary decisions $\left\{\#<e_{g, h}: e_{i, j}>\right\}$ in different areas of decision- making $\mathrm{OD}_{\mathrm{h}}, \mathrm{OD}_{\mathrm{j}}$ for each of the analyzed decisionmaking problem $\mathrm{PD}$.

Sets of pairs of contradictions of elementary decisions can be used for flexible switching elementary decisions $e_{i, j}$ without having to change complex decisions $\mathrm{D}_{\mathrm{k}}$ or internal organization standards.

In the proposed mode of action, each "network of competence" corresponds to the specific objective of the organization and to the associated decision problems. So we have to deal with the situation when the hierarchical structure of decision-making problems and their solutions are subordinated to the structure of the organization. 
Methodology of the proceedings in the construction of the network of competence, proposed in this paper for the implementation of management purposes, presented at the three-layer model HSD will be presented in the next article as an attempt to dynamically balance the decision-making processes. HSD model can be expanded or reduced to reach the necessary number of decision layers and paths in compliance with integrally formulated restrictions and mechanisms of standardization. This direction of further research, results from the need how effectively compare decisions and their consequences.

\section{$7 \quad$ Bibliography}

[1] Domański, J., Kotarba, W., Krupa, T., 2014. The Prisms of Management. Foundations of Management - International Journal, Warsaw: WUT, Vol. 6, No. 2, pp.43-50, DOI: 10.1515/fman2015-0010. [online] Available at: https://www. degruyter.com/view/j/fman

[Accessed on 11 December 2016].

[2] Ficoń, K., 2007. Inżynieria zarzq̨dzania kryzysowego. Podejście systemowe (Engineering Crisis Management. Systems Approach). Warszawa: BEL Studio.

[3] Gorbatov, V.A., 1979. Semanticeskaja teorija projektirovanija avtomatov (Semantic Theory of Automata Design). Moskva: Izd. Energija.

[4] Gorbatov, V.A., Krupa T., 1984. Zasada charakteryzacji $w$ logistyce systemu produkcyjnego (The Principle of Characterization in Logistics of Production System). Int. Conf. Sypro'84. Systemy Produkcyjne - Teoretyczne i Praktyczne Problemy Projektowania (Manufacturing Systems - Theoretical and Practical Design Problems), Warszawa: OW PW, pp.213-218.

[5] Jajuga, K., (red.), 2007. Zarzqdzanie ryzykiem (Risk Management). Warszawa: PWN.

[6] Kieżun, W., 1997. Sprawne zarzqdzanie organizacja. Zarys teorii i praktyki (Efficient Management of the Organization. Outline of Theory and Practice). Warszawa: Wydawnictwo SGH.

[7] Korzeniowski, L.F., 2012. Podstawy nauk o bezpieczeństwie. Zarządzanie bezpieczeństwem (Basics Science of Safety. Security Management). Warszawa: Difin.
[8] Krupa, T., 1998. Model systemu wspomagania rozmytych procesów decyzyjnych (Model of Support System of Fuzzy Decision-Making Processes). In: Knosala, R. (ed.). Komputerowo zintegrowane zarzadzanie (Computer Integrated Management). Warszawa: WNT, pp.203-212.

[9] Krupa, T., 2005. O pewnej specyfikacji procesu produkcyjnego (On Some Specification of Decision-Making Process). Problemy Zarzadzania (Management Problems). Warszawa: Wydawnictwa Naukowe Wydziału Zarządzania UW, No. 1, pp.79-88.

[10] Krupa, T., 2006. Elementy organizacji. Zasoby $i$ zadania (Elements of the Organization. Resources and Tasks). Warszawa: WNT.

[11] Krupa, T., 2009a. Events and Events Processes. Foundations of Management - International Journal, Warsaw: WUT, Vol. 1, No. 2, pp.143158. Available at: https://www.degruyter. com /view/j/fman [Accessed on 11 December 2016].

[12] Krupa, T., 2009b. Modelowanie Procesów Dyskretnych w Aksjomatyce Teorii Charakteryzacji Gorbatov'a (Modeling of Discrete Processes in Gorbatov Axiomatic Theory of Characterization). In: T., Krupa, (ed.). Wybrane zagadnienia informatyki gospodarczej (Selected Issues of Digital Economi). Warszawa: Oficyna PTZP, pp.127-164.

[13] Krupa, T., 2013. V.A. Gorbatov Theory of Characterization - Principles and Examples. Foundations of Management - International Journal, Warsaw: WUT , Vol. 5, No. 3, pp.89-102. [online] Available at: https://www.degruyter. com/view/j/fman [Accessed on 11 December 2016].

[14] Krupa, T., 2014. Operacje na sieciach zdarzeń (Operations on Network Events). Logistyka (Logistics), No. 5, pp.851-861, CD1.

[15] Krupa, T., Ostrowska, T., 1990. The Logical Aspects of Task and Resource Design. Int. Conf. Cybernetics and Systems'90. World Scientific, University of Vienna, pp.267-274.

[16] Krupa, T., Ostrowska, T., 2007. Multilayer Decision Supper Model for Value and Cost Analysis of IT Solutions - Hierarchical Approach. In: Managing Worldwide Operations and Communications with Information Technology. IRMA 
Int. Conf., pp.86-90. Vancouver - Canada: IGI Publisging.

[17] Krupa, T., Ostrowska, T., 2012. Decisionmaking in the Flat and Hierarchical Decision Problems. Foundations of Management - International Journal, Warsaw: WUT ,Vol. 4, No. 5, pp.23-36. [online] Available at: https://www. degruyter.com/view/j/fman

[Accessed on 11 December 2016].

[18] Krupa, T., Wiśniewski, M., 2015. Situational Management of Critical Infrastructure Resources under Threat. Foundations of Management - International Journal, Warsaw: WUT , Vol. 07, No. 1, pp.93-104. [online] Available at: https://www.degruyter.com/view/j/fman [Accessed on 11 December 2016].

[19] Kulińska, E., 2012. The Risk Assessment in the Logistic Processes Structures. Foundations of Management - International Journal, Warsaw: WUT, Vol. 04, No. 1, pp.43-62. [online] Available at: https://www.degruyter.com/view/j/fman [Accessed on 11 December 2016].

[20] Maj, K., Krupa, T., 2010. The Management Method Preventing a Crisis Situation. Foundations of Management - International Journal, Warsaw: WUT, Vol. 02, No. 02, pp.37-50. [online] Available at: https://www.degruyter. com/view/j/fman

[Accessed on 11 December 2016].

[21] Ostrowska, T., 2013. The Resource Hazards Model for the Critical Infrastructure of the State Emergency Management Process. Foundations of Management - International Journal. Warsaw: WUT, Vol. 5, No. 3, pp.49-60. [online] Available at:https://www.degruyter.com/view/j/fman [Accessed on 11 December 2016].

[22] Ostrowska, T., Krupa, T., Wiśniewski, M., 2015. Dynamic Hazards in Critical Infrastructure of State. Foundations of Management - International Journal, Warsaw: WUT, Vol. 7, pp.143158. [online] Available at: https://www. degruyter.com/view/j/fman [Accessed on 11 December 2016].

[23] Pawlak, Z., 1991. Rough Sets. Theoretical Aspects of Reasoning about Data. Dordrecht: Kluwer.

[24] Zadeh, L., 1965. Fuzzy Sets. Information and Control, No. 8, pp.338-353

[25] Zawiła-Niedźwiecki, J., 2008. Ciagłość Działania Organizacji (Continuity Activities Organization), Warszawa: Oficyna Wydawnicza Politechniki Warszawskiej.

[26] Zawiła-Niedźwiecki, J., 2009. Operational Risk and The Security of an Organization. In: J., Monkiewicz, L., Gąsiorkiewicz (eds.). Risk Management. Concepts, Models, Issues. Warszawa: Dom Wydawniczy Elipsa.

[27] Zawiła-Niedźwiecki, J., 2010. Business Continuity. Foundations of Management - International Journal. Warsaw: WUT, Vol. 2, No. 2, pp.101118. [online] Available at: https://www. degruyter.com/view/j/fman [Accessed on 11 December 2016].

[28] Zawiła-Niedźwiecki, J., 2014. Operational Risk as a Problematic Triad: Risk-Resource Security-Business Continuity. Kraków: edu-Libri.

[29] Zwicky, F., 1969. Discovery, Invention, Research Through the Morphological Approach. New York: The MacMillan. 